\title{
Doğal Sitlerde Derecelendirme Sorunu: Elazığ-Hazar Gölü Örneği
}

\author{
The Problem With Grading Natural Protected Areas: A Case Study of Elazığ-Hazar \\ Lake
}

\author{
Aysun TUNA * \\ Dr. Öğr. Üyesi, İnönü Üniversitesi, Güzel Sanatlar ve Tasarım Fakültesi Peyzaj Mimarlığı Bölümü, 44280, Battalgazi, \\ Malatya Türkiye
}

\section{ÖZET ABSTRACT}

Doğal sit, 2863 sayılı Kanunun 3.Maddesinin a bendinde yer alan tanımlara göre; jeolojik devirlere ait olup, ender bulunmaları nedeniyle olağanüstü özelliklere sahip yer üstünde, yeraltında veya su altında bulunan korunması gerekli alanlar olarak tanımlanmaktadır. Korunan alanlar olarak doğal sitlerin belirlenmesi, sınıflandırılması ve kamunun mülkiyet hakları ile ilgili önemli sorun ve kargaşalar yaşanmaktadır. Doğal sit derecelendirme sürecinde başlıca sorunlardan biri, doğal sitlerin günce durumlarının değerlendirilerek mevcut ve yeni ilan edilecek doğal sit kategorilerini ortaya koyan ekolojik araştırma ve metodolojik yaklaşımlarla kararların üretilememesidir. Ekolojik planlama ve koruma ölçütlerine göre alınması gerekli bilimsel kararların yerine subjektif ve değişebilen kararlar alınarak gerçekleştirilen uygulamalarda yerel halk ile resmi kurum ve kuruluşlar karşı karşıya getirecek mağduriyetler yaşanmakta diğer taraftan yapılaşma doğrultusunda verilen kararlar ile doğal sitlerin ekolojik karakterlerinin bozulması tehdid baş göstermektedir. Bu çalışmada, farklı doğal sit derecelendirmelerine sahip Elazığ İ sınırları içinde yer alan Hazar Gölü çevresindeki taşınmazlara ilişkin İl İdare Mahkemesi tarafından nihai kararı verilen ve yazarın bizzat bilirkişi olarak görev yaptığı dava sürecinde yapılan incelemeler ve karar alma süreci aktarılmıştır. Bu çalışma ile birlikte doğal sitlerde yaşanan yapılaşma sorunlar kapsamında yapılacak saha araştırmaları ile kamu kurum ve kuruluşlarının hazırlamış oldukları raporlar ile karşılaştırılarak sorun tanımlanmış ve çözüme yönelik öneriler geliştirilmiştir. Yapılan araştırmalara ilişkin olarak bu çalışmanın bilirkişilik faaliyetlerinde bulunacak peyzaj mimarları ve diğer ilgili meslek disiplinlerinde çalışanlara yol göstermesi hedeflenmiştir.

Anahtar Kelimeler: Doğal sit, Hazar Gölü (Elazığ), Bilirkişilik
Natural protected areas are defined as rare areas with extraordinary features, thus having an important conservation value which are found above and under the surface of the ground and water, which date back to geologic periods according to the Paragraph a of the 3rd Article under the Law No. 2863. The identification and classification of the natural protected areas lead to some difficulties and complexities in terms of property rights. One of the leading problems with the grading process of the natural protected areas is the difficulty of producing ecological research and methodological approaches by evaluating the current situation of the natural areas. Instead of taking scientific decisions in line with the ecologic planning and conservation criterion, subjective and variable decisions can be made for implementations: therefore the citizens may clash with institutions and organizations from time to time. On the other hand, some decisions made on settlements may threaten the ecologic characteristics of natural protected areas.

In this study, the final ruling of the regional administrative court regarding the immovable properties located around Hazar Lake which fall into the provincial borders of Elazığ, a city with various natural protected area degrees and the investigations in which the author herself participated as an expert as well as the decision making process are explained. The on-site research including the illegal housing on natural protected areas as well as the reports drafted by public institutions and organizations are compared and solution offers are presented in this study. In addition to the conducted researches, this study aims at providing guidance for landscape architects that will act as experts as well as for other professionals from various disciplines.

Keywords: Natural protected area, Hazar Lake (Elazığ), Expert report

\section{GİRIŞ}

Nüfus artışı, sanayileşme, şehirleşme gibi faktörler, doğal kaynakları tehdit etmektedir. İnsanlığın ortak mirası olan doğal kaynakların kirletilmesi; bilinçsiz, umursamaz ve kontrolsüz yapılan avlar, ağaç kesimleri; koruma amacı gütmeyen yapılaşmalar, madencilik faaliyetleri, yol açma çalışmaları, köprü, havaalanı ve baraj yapımları, bataklıkların ve sulak alanların kurutulması, orman yangınları; çevreye zararlı atıkların uygun koşullarda yok edilmemesi, filtrelenmemesi, savaşlar gibi olumsuz gelişmeler doğanın korunması gerekliliğini ortaya çıkarmıştır (Eröksüz, 2016).

Dünya'da koruma bilinci Endüstri Devrimi'nin neden olduğu çevre sorunlarının ortaya çıkışı ile parallellik göstermiştir. Özellikle 19.yy'da ortaya çıkan örgütlü çalışmalar, uluslararası işbirlikleri ile önemli gelişmeler kaydedilmiştir. Koruma konusunda ilk sistemli yaklaşımın temelleri, 1872 yılında Ulusal Park ilan edilen Yellowstone Ulusal Parkı ile atılmıştır. Ardından çok sayıda ülke, geleceğe yatırım olarak gördükleri korunan alanların hızla ilan edilmesini sağlamıştır (Kurdoğlu, 2007).

* Corresponding author

E-mail address: aysun.tuna@inonu.edu.tr

http://dx.doi.org/10.16950/iujad.321762 
ABD'de milli park hareketi ile başlayan doğal alanların korunması çalışmaları, 1948 yılında UNESCO bünyesinde Dünya Doğayı Koruma Birliği (IUCN)'nin kurulması ile örgütlü hale gelmiştir. IUCN (International Union for Conservation of Nature and Natural Resources) korunan alanları; doğa ile ilgili ekosistem servisleri ve kültürel kaynakların korunması ve devam ettirilmesine adanmış, yasal veya diğer etkili yöntemlerle yönetilen, açıkça tanımlanmış coğrafi alanlar olarak tanımlamıştır (IUCN, 2008).IUCN; Korunan alanların, (milli parklar, yaban hayatı, doğal rezerv alanları ve benzeri) biyolojik çeşitliliğin korunmasının temelini oluştururken, aynı zamanda insanların yerel düzeydeki yaşamlarına da katkıda bulunduklarını, doğayı ve topluma sunduğu hizmetler -gıda, temiz su temini, ilaçlar ve doğal afetlerin etkilerinden korunma - bakımından korumaya yönelik çabaların merkezinde yer aldığını, iklim değişikliği etkilerini azaltmada yardımcı olmadaki rollerinin giderek daha fazla arttığını bildirmektedir (IUCN, 2008). IUCN tarafından korunan alanlar; mutlak doğa rezervi ve yabanıl alan (tabiat rezervi, yaban hayatı alanı), milli park, tabiat anıtı, yaşam tür koruma alanı, kara/deniz peyzajını koruma alanı, yönetilen doğal kaynak koruma alanı, olmak üzere 6 kategoriye ayrılmıştır (IUCN, 2016). IUCN, korunan alanlar dışında; biyolojik çeşitlilik, iklim değişikliği, ekonomi, ekosistem yönetimi, çevre kanunları, ormanlar, cinsiyet eşitliği, küresel politikalar, sosyal politikalar, kutuplar ve denizler, sulak alanlar, özel türler, dünya miras alanları gibi birçok farklı başlıklarda faaliyetlerini kuruluş yılından bugüne kadar sürdürmektedir (Dudley, 2008).

IUCN tarafından örgütlü hale gelen doğa koruma hareketlerine paralel olarak, 1900'lü yıllarda imzalanan doğa koruma kapsamında yapılan uluslararası sözleşmeler önem arz etmektedir. Ramsar Sözleşmesi, CITES (Nesli Tehlike Altında Olan Yabani Hayvan ve Bitki Türlerinin Uluslararası Ticaretine İlişkin Sözleşme), Bonn Sözleşmesi ve Dünya Doğal ve Kültürel Mirasının Korunması Sözleşmesi, korumada uluslararası normların belirlendiği ve taraf olan ülkeler tarafından kendi iç yönetim mekanizmalarında yürütülmesi sorumluluk ve zorunluluğunu taşıyan maddeleri kapsamaktadır. 1990’lı yıllardan itibaren, bu sözleşmelerin temelini oluşturduğu dünya ve Avrupa ölçeğinde geliştirilen çeşitli koruma programlarının da katkısıyla, bugün dünya yüzeyinin \%10'undan fazlasını çeşitli statülerde koruma başarısına ulaşılmıştır (Vuruşkan ve Ortaçeşme, 2009).

Yirminci yüzyılda ise, korunan alanlar için ortak standartlar ve terminoloji oluşturulmadığından her ülke kendi yönetim anlayışını geliştirmekteydi. Terminoloji oluşturmadaki ilk adım 1933 yılında Londra'da yapılan Uluslararası Fauna ve Flora Koruma Konferansı'nda atılmıştır. Konferans sonucunda Milli Park, Mutlak Doğa Koruma Alanı, Fauna ve Flora Koruma Alanı, Avcılık ve Toplayıcılığa Yasak Alanlar, olarak korunan alan türleri belirlenmiştir (Dudley, 2008).

Türkiye'de doğal kaynakları korumada ilk uygulama, Osmanlı Devleti döneminde İstanbul'un tatlı suyunu karşılayan koruları koruma altına alan 1870 yılında yürürlüğe giren Orman Nizamnamesi'dir (Koç, 2006). Türkiye Cumhuriyeti döneminde korumadaki anayasal düzenleme ise, 1937 yılında yürürlüğe giren 3116 sayılı Orman Kanunu ile başlamıştır. Türkiye'de doğa koruma uygulamaları; Su Ürünleri Kanunu, Eski Eserler Kanunu, Milli Parklar Kanunu, Çevre Kanunu, Kültür ve Tabiat Varlıklarını Koruma Kanunu, Özel Çevre Koruma Kurumu Başkanlığı Kurulmasına Dair KHK, Kıyı Kanunu, Milli Ağaçlandırma ve Erozyon Kontrolü Seferberlik Kanunu, Mera Kanunu, Orman ve Su İşleri Bakanlığı'nın Teşkilat ve Görevleri hakkında KHK, Çevre ve Şehircilik Bakanlığı'nın Teşkilat ve Görevleri Hakkındaki KHK gibi yasal düzenlemeler ile güvence altına alınması sağlanmıştır (Eröksüz, 2016).

Türkiye'nin de taraf olduğu uluslararası koruma statüleri; Dünya Kültürel ve Doğal Mirasının Korunmasına Dair Sözleşme, Avrupa'nın Yaban Hayatı ve Yaşama Ortamlarını Koruma Sözleşmesi, Zümrüt Ağı Alanları, Barselona Sözleşmesi ve Akdeniz'de Özel Koruma Alanlarına İlişkin Protokol, Ramsar Sözleşmesi, AB Kuşları Koruma Yönetmeliği, Avrupa Birliği Habitatları ve Türleri Koruma Yönetmeliği ile Natura 2000 Alanları olarak belirlenmiştir (Gökçeoğlu ve Ayaş, 2012).

Bugün, doğa koruma alanlarının sınıflandırılmasında ve yönetiminde ülkeler arasında farklılıklar bulunmaktadır. Genel olarak korumada zonlama sisteminin kullanıldığı bilinmektedir. IUCN tarafından kullanılan zonlama sistemi önemli veya tehlike altındaki habitatların, ekosistemlerin ve ekolojik süreçlerin korunmasında, zararlı olabilecek insan aktivitelerini sınırlamada, makul ölçülerde arazi kullanımına olanak tanırken doğal ve/veya kültürel değerleri korumada, zarar görmüş alanların iyileştirilmesinde kullanılmaktadır. Zonlama, doğa koruma alanının alt bölgelere ayrılmasıdır. Bu alt bölgeler için ayrı uygulama hedeflerini içeren tip ve yoğunluk farklılıklarına göre yönetim faaliyetleri uygulanmaktadır (TMMOB Orman Mühendisleri Odası, 2018).

Doğa koruma alanlarının zonlama sistemleri ülkelere göre farklılıklar göstermektedir. Örnek olarak, IUCN tarafından zonlama sistemin en iyi uygulandığı yer olarak seçilen İtalya'daki Abruzzo Milli Parkı, 4 zona ayrımıştır. Zon A (Mutlak Koruma Alanı), bilimsel araştırmalar 
dışında alana giriş izninin olmadığı ya da özel izinle olduğu bu alanın önemli bir kısmının mülkiyeti yerel halka aittir. Devlet tarafından koruma altına alınan bu topraklar üzerinde yerel halka kira ödemeleri yapılmaktadır. Zon B (Genel Rezerv Alanı), tüm alanın büyük bir bölümünü kapsayan alanda ormanlık alanlar bulunmaktadır. Bu alanlarda kontrollü geleneksel üretim ve ekonomik faaliyetlerin devamlılı̆ı serbestliği tanınmıştır. Zon C (Korunan Peyzaj Alanı), tarım arazilerinden oluşmaktadır. Zon D (Gelişme Zonu) milli parkın koruma zonu olarak işlev gören yerleşim alanlarının bulunduğu alandır (URL-1, 2018).

Kanada'daki milli parklardaki zonlama sistemi, erişime izin verilmeyen kırılgan kaynakların bulunduğu Özel Koruma Zonu, park ekosistemlerinin en iyi sergilendiği, yaban hayatı korumanın esas olduğu Yabanıl Zon, doğal yapının korunduğu yerel halkın sınırlı geçişine izin verildiği Doğal Çevre Zonu, eğitim, açık hava rekreasyonu, konaklama ve ziyaretçilere yönelik tesislerin yer aldığı ve araç girişine izin verildiği Açıkhava Rekreasyon Zonu, park yönetimi için gerekli ana hizmet birimlerinin ve tesislerinin yer aldığı Park Hizmetleri Zonu olarak ayrılmıştır (URL-2, 2018)

ABD'de korunan alanlar; ulusal düzey, eyalet düzeyi ve yerel yönetimler düzeyinde farklı koruma seviyeleri ile yönetilmektedir. Eyalet düzeyinde korunan alanlar, çoğu Amerika Birleşik Devletleri İçişleri Bakanlığı bürosu olan Ulusal Park Servisi'nin bir parçası olan çeşitli kurumlar tarafından yönetilmektedir. Federal düzeyde korunan alanlar, IUCN tarafında tanımlanan Seviye 1 (Doğal Rezervler ve Yaban Hayatı Alanı) ile Seviye 2 (Ulusal Parklar) düzeyinde korunmaktadır. Bünyesinde taşınmaz kültür varlıklarının bulunduğu federal düzeyde korunan alanlarda Tarihsel Koruma Zonu bulunmaktadır. Diğer korunan alanlar; rekreasyonel faaliyetlerin yapılabileceği kent kullanıcılarının erişimine açık, ulusal düzeyde bölge parkları, yerel düzeyde kent parkları olarak adlandırılmaktadır. Her biri kendi düzeyinde kontrol ve yönetim mekanizmasına sahiptir (IUCN, 2016).

Türkiye'de korunan alanlardaki zonlama sistemleri, IUCN'nin sınıflandırmaları ile benzerlik gösterirken farklılıklar da bulunmaktadır. Bu farklılıklardan en çok dikkat çekeni "doğal sit" kavramıdır. Doğal sit kavramı Türkiye'ye özel bir kavramdır. Bu tanım Türkiye dışındaki ülkelerde kullanılmamaktadır. Ayrıca, taraf sıfatı ile Türkiye'nin imza attığı uluslararası antlaşma metinlerinde de doğal sit tanımı yapılmamıştır (Eröksüz, 2016). Türkiye'de, doğal kaynakların korunmasında en son yürürlükte olan ve 08.08.2011 tarihinde 648 sayılı KHK ile 2863 sayılı Kültür ve Tabiat Varlıklarını Koruma Kanunu'na tanımı ile eklenen "Doğal Sit" kavramı, yerel literatüre alınmıştır. Türkiye'de doğal sitler ile ilgili koruma biçimini belirleme ve onaylama yetkisi T.C. Kültür ve Turizm Bakanlığı'na bağlı Kültür ve Tabiat Varlıklarını Koruma Yüksek Kurulu ile yüksek kurullara bağlı yerel kurullarda bulunurken, 644 sayılı KHK ile yetki, T.C.Çevre ve Şehircilik Bakanlığı'na bağlı Tabiat Varlıklarını Koruma Genel Müdürlüğü ile Çevre ve Şehircilik İl Müdürlükleri'ne devredilmiştir. Yürürlüğe giren yeni yönetmelikle birlikte doğal sit tanımında değişiklikler yapılmıştır. 2863 sayılı Kültür ve Tabiat Varlıklarını Koruma Kanunu ve 728 sayılı Kültür ve Tabiat Varlıklarını Koruma Yüksek Kurulu ilke kararlarında: doğal (tabii) sit; jeolojik devirlerle, tarih öncesi ve tarihi devirlere ait olup, ender bulunmaları veya özellikleri ve güzellikleri bakımından korunması gerekli yer üstünde, yer altında veya su altında bulunan korunması gerekli alanlar olarak tanımlanmış ve doğal sit derecelendirmeleri yapılmıştır. İlke kararına göre doğal sitler;

I. Derece Doğal (Tabii) Sit: Bilimsel muhafaza açısından evrensel değeri olan, ilginç özellik ve güzelliklere sahip olması ve ender bulunması nedeniyle kamu yararı açısından mutlaka korunması gerekli olan, korumaya yönelik bilimsel çalışmalar dışında aynen korunacak alanlar,

II. Derece Doğal (Tabii) Sit: Doğal yapının korunması ve geliştirilmesi yanında kamu yararı göz önüne alınarak kullanıma açılabilecek alanlardır. Turizm yatırım ve turizm işletme belgeli turistik tesisler ile hizmete yönelik yapılar dışında herhangi bir yapılaşmaya gidilemeyen alanlar,

III. Derece Doğal (Tabii) Sit: Doğal yapının korunması ve geliştirilmesi yolunda, yörenin potansiyeli ve kullanım özelliği de göz önünde tutularak konut kullanımına da açılabilecek alanlar, olarak tanımlanmıştır.

Bu alanlarda, kullanıma açılacak bölgelerde geçici dönem yapılanma koşullarının ilgili kurumların görüşleri alınarak koruma kurullarınca belirlenmesine, bu belirlemede varsa 1 /25.000 ölçekli çevre düzeni planı veya 1/5.000 ölçekli nazım planı kararları ile arazinin topografya, peyzaj, siluet vb. karakteristiklerinin göz önünde tutulması ön görülmüştür. Hazırlanacak Koruma Amaçlı İmar Planı kriterlerini etkileyebilecek nitelik ve yoğunluktaki uygulamalara Koruma Amaçı İmar Planı yaptırılmadan izin verilemeyeceğine, mevcut tarımsal ve hayvancılık faaliyetlerinin sürdürülebilmesinin yanı sıra ilgili koruma kurullarından izin almak koşulu ile yeni tarımsal ve hayvancılık faaliyetlerinin yapılabileceğine, doğal peyzaj ve siluet dikkate alınarak koruma kurulunca belirlenecek koşullar doğrultusunda kum, çakıl, taş, maden ve benzeri malzeme alınabileceğine, bu amaçla ocak açılabileceğine, toprak, curuf, çöp, sanayi 
artığı ve benzeri dökülemeyeceği ile ilgili koşullar belirtilmiştir (Kültür ve Turizm Bakanlığı, 1999)

2863 sayılı Kanunun 3. Maddesinin a bendinde yer alan tanımlara göre doğal sit tanımı; "jeolojik devirlere ait olup, ender bulunmaları nedeni ile olağanüstü özelliklere sahip yer üstünde, yer altında veya su altında bulunan korunması gerekli alanlar" olarak tanımlanmıştır. Yürürlükteki tanımda ilke kararında yer alan "tarih öncesi ve tarihi devirlere ait olma" kriteri çıkarılarak "doğal sit" ve "tabiat varlıkları" kavramları içerik olarak birbirinden ayrılmıştır. Bir başka ifade ile, "tabiat varlığı" mağara, anıt ağaç, ağaç toplulukları gibi korunması gereken doğal varlıkları ifade ederken, "doğal sit" korunması gerekli doğal bir alanı ifade etmektedir (Çevre ve Şehircilik Bakanlığı, 2013).

2863 sayılı Kültür ve Tabiat Varlıklarını Koruma Kanunu ve 728 sayılı Kültür ve Tabiat Varlıklarını Koruma Yüksek Kurulu ilke kararlarında; doğal sit tanımı yapılmış ancak derecelendirmeye esas koşullara ilişkin yoruma açık ve göreceli ifadeler kullanılması ve bilimsel temellere dayalı tanımların olmaması nedeni ile doğal sit derecelendirmelerinde sorunlarla karşılaşılmıştır. Doğal sitlerle ilgili uygulamalarda yaşanan sorunlar nedeni ile 644 sayılı KHK ile doğal sitlerin korunması sorumluluğu Çevre ve Şehircilik Bakanlığı'na devredilmiştir. Yürürlüğe giren yeni yönetmelik ile doğal sitler; Kesin Korunacak Hassas Alanlar, Nitelikli Doğal Koruma Alanları, Sürdürülebilir Koruma ve Kontrollü Kullanım Alanları başlıkları altında 3 kategoride yeniden ele alınmıştır.

Kesin Korunacak Hassas Alanlar, Bakanlar Kurulu kararı ile ilan edilecek bu alanlara yapı yasağı getirilerek ve bu alanlarda bilimsel çalışmalar hariç tüm kullanımların sınırlandırılacağı,

Nitelikli Doğal Koruma Alanları, koruma amaçlarına uygun olarak yörede yaşayanların alanın mevcut kaynaklarını kullanmasını sağlayarak doğal hayata dayalı geleneksel yaşam şekillerinin korunacağı,

Sürdürülebilir Koruma ve Kontrollü Kullanım Alanları, kesin korunacak hassas alanlar veya nitelikli doğal koruma alanlarını etkileyen, bu koruma bölgeleri ile bütünlük gösteren, korumaya katkı sağlayacak, doğal ve kültürel bakımdan uyumlu, düşük yoğunlukta faaliyetler, turizm ve yerleşimlere izin verilebilecek, alanlar olarak tanımlanmaktadır (Çevre ve Şehircilik Bakanlığı, 2013a).

Doğal sit kategorilerinin belirlenmesi aşamaları, alanın sahip olduğu biyolojik, ekolojik (flora, fauna, habitat), jeolojik, hidrojeolojik, jeomorfolojik ve peyzaj değerleri ile bu alanların sınırlarının belirlenmesi amacı ile T.C Çevre ve Şehircilik Bakanlığı Tabiat Varlığı Koruma Genel Müdürlüğü'nün 2013 yılında yayınladığı Doğal Sit Alanların Değerlendirilmesine ilişkin Teknik Esaslar adlı çalışmada yer almaktadır (Çevre ve Şehircilik Bakanlığı, 2013b). Teknik raporun yasal dayanağını 2863 sayılı Kanun, 644 sayılı KHK'nin madde 13/A ile; 19.07.2012 tarihli ve 28358 sayılı Resmi Gazetede yayımlanarak yürürlüğe giren "Korunan Alanların Tespit, Tescil ve Onayına İlişkin Usul ve Esaslara Dair Yönetmelik" oluşturmaktadır (Resmi Gazete, 2012). İlgili yönetmelik uyarınca herhangi bir korunan alanın güncel durumu tespit edilmeden, o alanın korunan alan statüsü yeniden değerlendirilemeyecek; bu alanların güncel durumu ise, alanın biyolojik çeşitliliği, hidrolojisi, hidrojeolojisi başta olmak üzere her açıdan durumu ekolojik temelli bilimsel araştırma yapılarak belirlenmesi gerekliliği üzerinde durulmuştur.

Türkiye'de doğal kaynak değerlerini içeren doğal sitlerin koruma ve kullanma koşullarına ilişkin kararların iptali istemi ile yerel halk, özel firmalar ya da kamu kurumları tarafından açılan davalar, ülke gündeminde sıklıkla yer almaktadır. Çalışmanın bu bölümünde; yasal-yönetsel, planlama ve uygulama açısından uyuşmazlıklara sebep olan danıştay kararları ile sonuca ulaşmış bazı dava konuları incelenmiştir.

Çalışma kapsamında; doğal sit olarak ilan edilen ve derecelendirilmesi yapılan alanlarda oluşan uyuşmazlığı temsil etmesi bakımından, Adana kenti Yumurtalık ilçesi sınırları içinde yer alan Türkiye'nin en büyük deltası olan Çukurova Sulak Alan Ekosisteminin en büyük parçası olan Yumurtalık Lagünleri, seçilen ilk örnek olmuştur. Yumurtalık Lagünleri, 19.11.1993 tarihinde Adana Kültür ve Tabiat Varlıklarını Koruma Kurulu'nun 1609 sayılı kararı ile I.Derece Doğal Sit, 31.013.1994 tarihinde 94/5451 sayılı Bakanlar Kurulu kararı ile Tabiatı Koruma Alanı ilan edilerek koruma altına alınmıştır. 09.02.2005 tarihinde Ramsar Sözleşmesi Listesi'ne dâhil edilmiştir. 2008 yılında Yumurtalık Lagünleri Yönetim Planı yürürlüğe girmiştir (Doğa Koruma ve Milli Parklar Genel Müdürlüğü, 2013). Yumurtalık Lagünü, 06.12.2008 tarih ve 27076 sayılı Resmi Gazete'de yayımlanan 2008/14355 sayılı Bakanlar Kurulu Kararı ile "Tabiatı Koruma Alanı" statüsü kaldırılarak "Milli Park" statüsüne dönüştürülmüştür. Ancak, İskenderun Çevre Koruma Derneği ile Yumurtalık Balıkçıları Kalkındırma Yaşatma ve Yumurtalık Doğa Çevre Koruma ve Güzelleştirme Derneği tarafından açılan davada, Danıştay 10. Dairesi; davaya konu olan Yumurtalık Lagünü 'nün Bakanlar Kurulu Kararına gerekçe olan koruma alanı niteliğini yitirdiğine ilişkin herhangi bir durum olmadığı, aksine Ramsar Sözleşmesi uyarınca bu alanın 
doğal karakterini bozacak uygulamalardan kaçınılmasını ve koruma uygulamalarını geliştirmeyi temel alan uluslararası taahhüt ve sorumluluğuna aykırı hareket edilmesi gerekçesi ile. Bakanlar Kurulu Kararı'nı iptal etmiştir (Danıştay 10. Dairesi 2009/1713 E., 2014/895 K.).

Doğal sit statüsüne sahip bir alanda mülkiyet hakkı ile ilgili uyuşmazlığı konu eden başka bir dava konusu Aydın'ın Söke İlçesinde yaşanmıştır. Dava konusu uyuşmazlığın; davacının önceki tarihlerde I. derece doğal sit alanında kalan taşınmazın uzun süre kamulaştırımadığından zarara uğradığı gerekçesi ile ilgili zararın karşılanması talebi ile mahkemeye başvurması ancak tazminat talebinin reddine ilişkin işlemden kaynaklandığı, dava dosyasında belirtilmektedir. İlgili mahkemenin davacıya ait taşınmazların değerinin tespiti amacıyla yaptırılan keşif ve bilirkişi incelemesinde davacının taşınmazlardan doğal şartlardan ötürü (denizin gelgit alanında bulunması, su taşkını riskinin olması) tasarruf etme imkânının bulunmadığı ve bu nedenle taşınmazın kullanılmamasından kaynaklanan bir zarardan bahsedilemeyeceği belirtilmiştir. Diğer taraftan mevzuat incelendiğinde, doğal sit statüsünde bulunan taşınmazlar için hazine taşınmazları ile takas yapma imkânının olduğu bilinmektedir. Ancak takas işlemleri için Koruma Amaçlı İmar Planı gerekli olduğu ilgili mevzuatta bildirilmiştir. Koruma Amaçlı İmar Planının mevcut olmamasından, ek olarak uyuşmazlığa konu taşınmazın kamulaştırılması zorunlu bir statüde bulunmaması ve bu nedenle kamulaştırmasız el atma nedeni ile oluşan bir zarardan bahsedilemeyeceği gerekçesi ile davacının talebi reddedilmiştir (Danıştay 6. Dairesi 2015/4418 K.).

Doğal kaynak değerlerin korunması ve enerji üretimi konuları arasında büyük uyuşmazlıklara neden olan HES'ler (Hidroelektrik Santral) idare mahkemelerinin ve Danıştay'ın gündeminde sıklıkla yer almaktadır. Özellikle ÇED (çevresel etki değerlendirme) olumlu ya da gerekli değildir raporlarının iptali gerekçesi ile açılan davaların sayısının giderek arttığı bilinmektedir. Bu davalardan Rize Kenti Fındıklı İlçesi sınırları içinde yer alan aynı zamanda 1. derece doğal sit statüsüne sahip Abuçağlayan Deresi üzerinde kurulması planlanan HES hakkında "Çevresel Etki Değerlendirmesi Olumlu" kararı verilmesine ilişkin 04.04.2008 günlü, 2597 sayılı Çevre ve Orman Bakanlığı Çevresel Etki Değerlendirmesi ve Planlama Genel Müdürlüğü işleminin iptali istemiyle açılan davada; 4856 sayılı Çevre ve Orman Bakanlığı Teşkilat ve Görevleri Hakkında Kanun, 2872 sayılı Çevre Kanunu ve Çevresel Etki Değerlendirmesi Yönetmeliği ile davalı idareye verilen görev ve yetkilerin amacına ve belirlenen çevre politikalarına uygun olarak, projenin kapsamlı çevresel etkilerinin hesaplanıp, tespit edilen sorunların ve belirsizliklerin giderilmesi ve uyuşmazlığa konu proje ile aynı vadide kurulması planlanan diğer projeler birlikte değerlendirilerek uyuşmazlık konusu santral ve eklentilerinin çevreye vereceği zararın kapsamlı bir Çevresel Etki Değerlendirmesi çalışması ile tespit edilmesi gerekirken, bu hususlar gözardı edilerek, Rize Kenti, Fındıklı İlçesi sınırları içinde Abuçağlayan Deresi ve Vadisi üzerinde kurulacak HES projesi için davalı Çevre ve Orman Bakanlığı tarafından Çevresel Etki Değerlendirmesi Olumlu kararı verilmesinde hukuka ve mevzuata uyarlık görülmediği gerekçesiyle iptali yolunda Rize İdare Mahkemesince verilen 30.06.2010 günlü, E:2008/369, K:2010/311 sayılı kararı onanmıştır (Danıştay 14.Dairesi K: 2011/5369 K.) (Akgedik, 2013).

\section{MATERYAL VE YÖNTEM}

Araştırma alanı olan Hazar Gölü Havzası, Doğu Anadolu Bölgesi'nin Yukarı Fırat Bölümünde Elazığ sınırları içerisinde bulunmaktadır. Güneydoğu Toros Dağları arasında çöküntü üzerinde yer alan göl, $274,9 \mathrm{Km}^{2}$ lik göl havzası ve $78,8 \mathrm{Km}^{2}$ lik su yüzeyine sahip olup, güneybatıkuzeydoğu istikametinde ortalama $20 \mathrm{Km}$ uzunluğunda, güneydoğu-kuzeybatı istikametinde ise, ortalama 4,5 Km genişliğindedir (Duran ve Günek, 2007). Havza sınırları içinde 14 adet yerleşim merkezi bulunmaktadır. Hazar Gölü barındırdığı doğal ve kültürel unsurları ile çeşitli koruma statülerine sahiptir (Şekil 1). Diyarbakır Kültür ve Tabiat Varlıklarını Koruma Kurulu'nun 11.07.1991 tarih ve 856 sayılı kararı ile;

- Ylanlı Ada 1.Derece Doğal Sit Alanı, Kilise Adası ve çevresi (Batık Kent) ile Göl'ün doğu yakasındaki Yarım Ada 1. Derece Arkeolojik Sit Alanı,

- Göl'ün çevresini izleyen mevcut karayolu ile Göl arasındaki bölge 2. Derece Doğal Sit Alanı ve,

- Karayolunun üst kısmında kalan alanlar ise, 3.Derece Doğal Sit Alanı olarak kabul edilmiştir (Diyarbakır Kültür ve Tabiat Varlıklarını Koruma Kurulu Arşivi). 


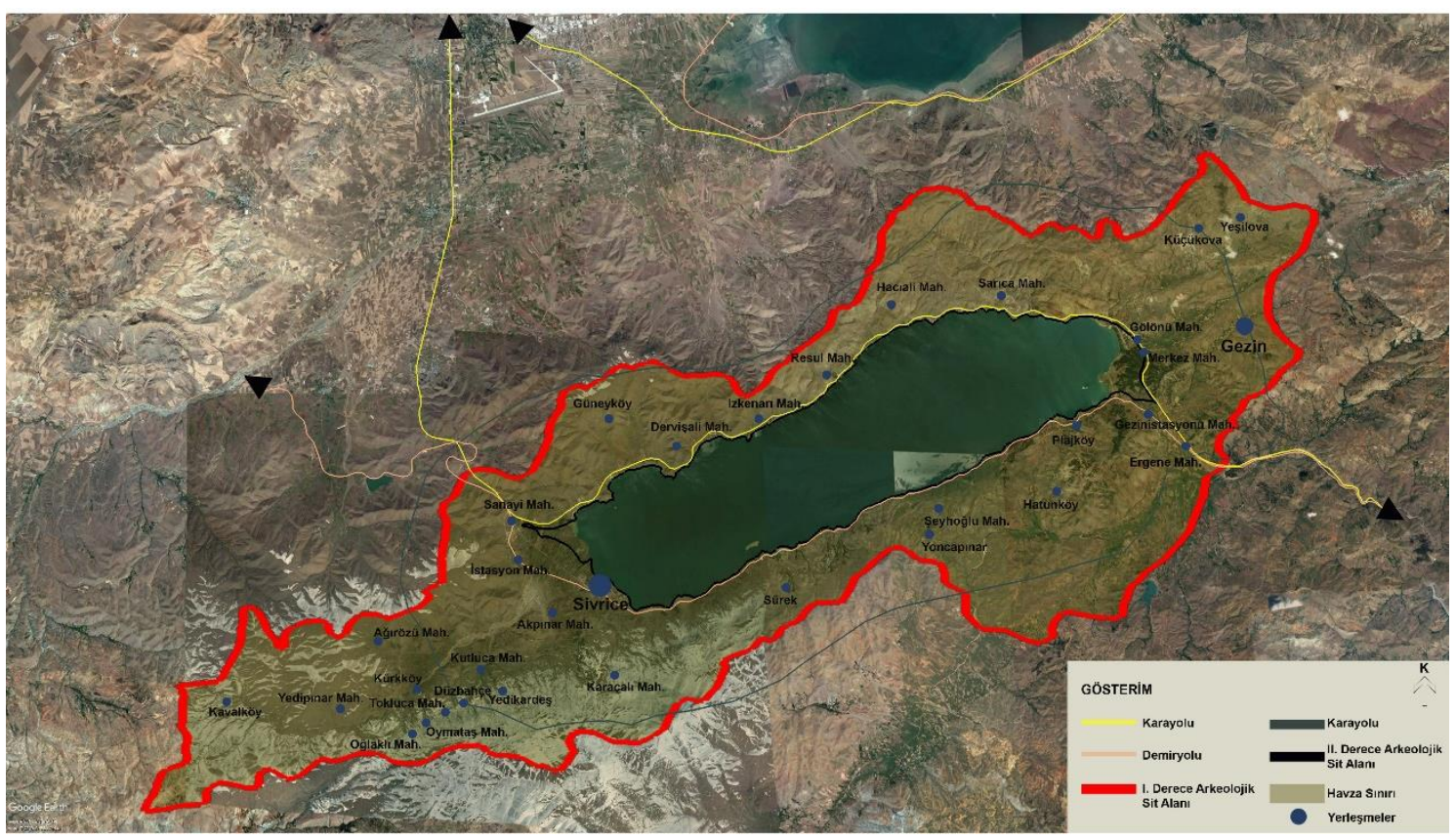

Şekil 1. Hazar Gölü Sit Alanı Sınırları (Çevre ve Orman Bakanlığı Doğa Koruma ve Milli Parklar Genel Müdürlüğü tarafından hazırlanan Hazar Gölü Yönetim Planından yararlanılarak hazırlanmıştır.) (Çevre ve Orman Bakanlığı, 2011).

Araştırmanın ana materyalini Elazığ Kenti, Hazar Gölü çeperinde yer alan konutların, 11.07.1991 günlü, 856 sayılı Diyarbakır Kültür ve Tabiat Varlıkları Koruma Kurulu kararı ile doğal sit içinde yer aldığı ve bu karara dayanarak yıkım işlerimlerinin başlatılmasına karşın konut sahipleri tarafından Diyarbakır Kültür ve Tabiat Varlıkları Koruma Kurulu kararının iptali istemi ile açılan dava sürecinde mahkeme tarafından dava konusu taşınmazın bulunduğu yerin çevre, peyzaj, topoğrafya, silüet vb, karekteristiklerinin göz önünde bulundurulması sureti ile doğal sit özellikleri taşıyıp taşımadığı ve taşınmazın özelliği itibari ile uygun olup olmadığının belirlenmesi amacı ile bir rapor hazırlanması" kapsamında oluşturulan bilirkişi heyetinin oluşturduğu bilirkişi raporu, oluşturmaktadır. Araştırmanın gerçekleştirilmesinde izlenilen yöntem; yazarın bizzat bilirkişi yetkisine dayalı olarak dava dosyası ile konu ile ilgili kurumlardan alınan ve talep edilen verilerin incelenmesi, çevre mühendisi, harita mühendisi, jeoloji mühendisi ve şehir plancısı ile gerçekleştirilen arazi-etüt çalışmaları ve arazi çalışmaları sonucunda elde edilen verilerin ve ilgili kurumların mahkemeye sunduğu raporlarla karşılaştırılması ile konuyla ilgili benzerlik taşıyan dava konularını içeren Danıştay kararlarının değerlendirilmesi olmak üzere üç etaplı olarak gerçekleştirilmiştir.

Araştırma kapsamında; Diyarbakır Kültür ve Tabiat Varlıklarını Koruma Kurulu kararları, Malatya-Elazığ-Bingöl-Tunceli 1/100.000 ölçekli Çevre Düzeni Plan kararları, Hazar Gölü Havzası'nda Biyolojik Çeşitliliğin Tespiti, Hazar Gölü Sulak Alan Yönetim Planı incelenmiş ve arazi etüt çalışmaları kapsamında değerlendirilmiştir. Elde edilen veriler kapsamında davaya konu olan taşınmazların bulunduğu alanın doğal sit karakteri taşıyıp taşımaması yönünde karar alma süreci aktarılmıştır.

\section{BULGULAR VE TARTIŞMA}

Hazar Gölü sağladığı uluslararası kriterler doğrultusunda Türkiye'nin Ramsar Alanı adayı olan 122 alanından birisidir. Hazar Gölü Sulak Alan Koruma Bölgeleri (Sulak Alan Bölgesi, Ekolojik Etkilenme Bölgesi, Mutlak Koruma Bölgesi ve Tampon Bölge) Sulak Alanların Korunması Yönetmeliği kapsamında belirlenmiştir (Çevre ve Orman Bakanlığı, 2011).

Çalışma alanı olan 39 adet konut amaçlı yapı topluluğu, Hazar Gölü'nün kuzey doğrutusundaki yamaçta inşa edilmiştir. Bu yapılar ile Hazar Gölü arasında kıyıya paralel Elazığ-Diyarbakır Karayolu geçmektedir. Söz konusu yapılar Hazar Gölü kıyısına 200m. mesafede konumlanmıştır. Konut topluluğu 2 katlı müstakil yapılar ve yapıya ait bahçelerden oluşmaktadır. Ayrıca, konutlar ile Hazar Gölü arasında Şebgen Köyü'ne ait konutlar da yer almaktadır (Şekil 2).

Arazi çalışmaları kapsamında yapılan incelemelere göre konutların yer aldığı Elazığ Diyarabakır Karayolu boyunca, bu yolun kuzey tarafında dava konusu konutların dışında yer 
yer birçok konut topluluğunun yapıldığı, bu konutların güneyinde ve Elazığ-Diyarbakır Karayolu ile Hazar Gölü arasında kalan bölgede, yer yer bazı köylere ait yapılar ile kamu kurumlarına ait tesislerin bulunduğu tespit edilmiştir. Dava konusu konutların bulunduğu alanın geneli kaya zeminlidir. Bu durum araştırma alanı içerisinde açılmış yarmalardan gözlemlenmiştir. Bu tür zeminler yerleşim açısından herhangi bir risk teşkil etmemektedir. Dava konusu sitenin bir paket arıtma tesisine sahip olduğu, ancak kurulduğundan beri kullanılmadığı, hatta elektrik bağlantısının yapılmadığı tespit edilmiştir. Dolayısıyla evsel nitelikli atıksular deşarj kriterlerine uygun olmadan direkt alıcı ortama verilmektedir. Bu durum çevresel sorunlara neden olmaktadır

Araştırmada öncelikle konutların yer aldığı arazinin doğal sit karakterinin belirleme süreci ile ilgili olarak "Doğal Sit Alanların Değerlendirilmesine İlişkin Teknik Esaslar" adlı rapor temel alınmıştır.

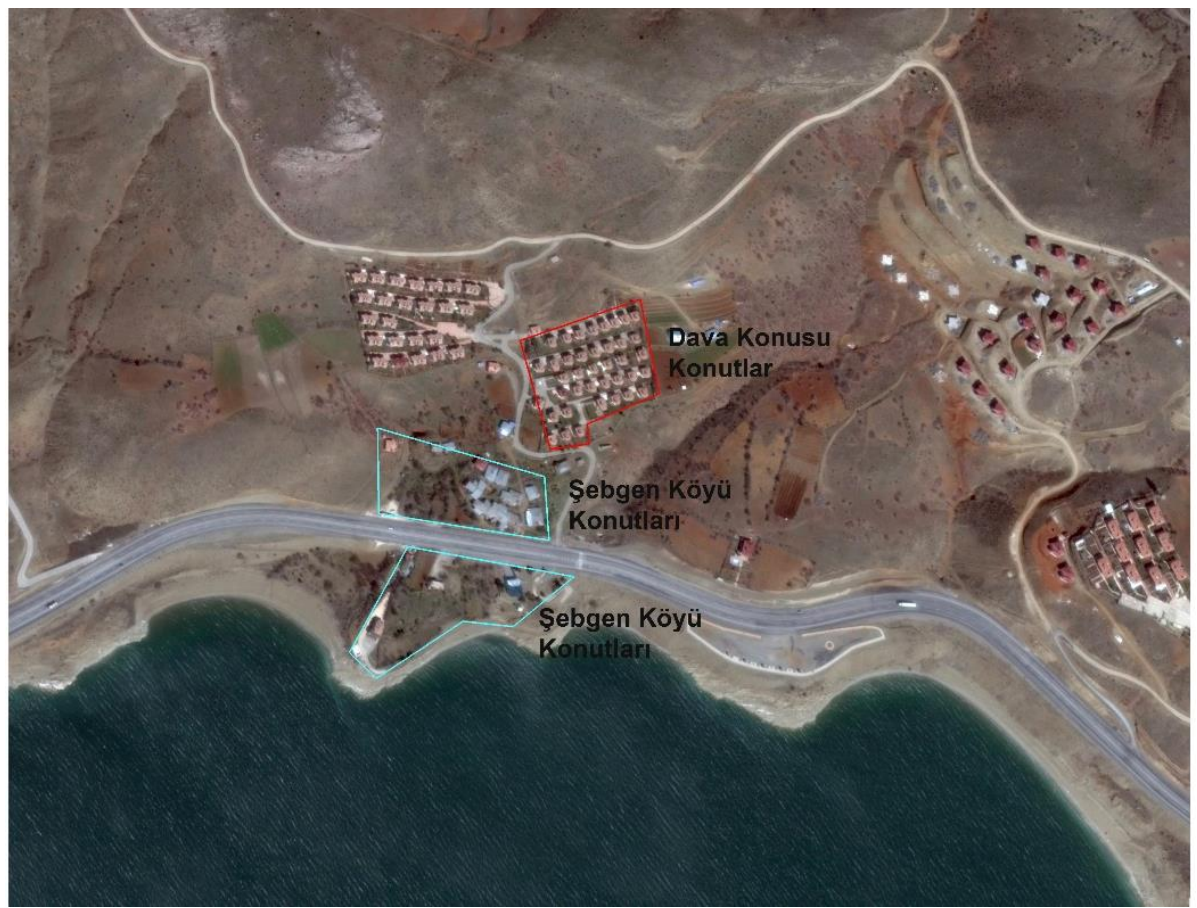

Şekil 2. Dava konusu konutların konumu (Google Earth uydu görüntüsünden üretilmiştir)

İlgili raporda, "mevcut alanların değerlendirilmesi ve yeniden tespit yapılması için öncelikle ön inceleme yapılır ve ön değerlendirme raporu düzenlenir. Ön değerlendirme raporu neticesinde, bilimsel araştırma çalışmasının gerekliliğinin ortaya konulması durumunda Ekolojik Temelli Bilimsel Araştırma Raporu, jeolojik, jeomorfolojik, hidrojeolojik ve peyzaj değerlerine ilişkin çalışmalar yapılır veya yaptırılır. Bu çalışma neticesinde alanın doğal sit karakterinde bir alan olup olmadığı ve/veya doğal sit kategorisi, yapılacak nitel (gözleme dayalı) ve nicel (sayısal) değerlendirmelerle belirlenir" ifadesi yer almaktadır. Bu ifadeden yola çıkılarak Hazar Gölü ve çevresi doğal sit sınırlarının belirlenmesi için bahsi geçen araştırma raporunun incelenmesi gündeme gelmiştir. Belirtilen teknik rapor Diyarbakır Kültür ve Tabiat Varlıklarını Koruma Kurulu'ndan talep edilmiştir. Ancak konu ile ilgili sunulan rapor sit derecelendirmesine ilişkin kapsamlı bilimsel veriler içermemektedir.

Davaya konu olan taşınmazlar ve üzerine inşa edilen konutların bulunduğu alan ile ilgili olarak, Kültür ve Turizm Bakanlığı Diyarbakır Kültür Tabiat Varlıklarını Koruma Kurulu tarafından 11.07.1991 tarih ve 856 sayılı karar alınmıştır. Bu kararda, gölün çevresini dolaşan mevcut karayolu ile göl arası II. Derece doğal sit alanı, karayolunun üst kısmında kalan alanlar ise III. Derece doğal sit alanı olarak ilan edilmiştir.

Davaya konu olan alan ile ilgili olarak Diyarbakır Kültür ve Tabiat Varlıklarını Koruma Kurulu'nun 11.07.1991 tarihli ve 856 sayılı kararı ile ilgili parsellerin III.Derece Sit Alanı olarak ilan edilen bölgede yer aldığı karar itibari ile; Kültür ve Tabiat Varlıklarını Koruma Yüksek Kurulu'nun Doğal Sitler, Koruma ve Kullanma Koşulları ile ilgili 728 sayılı ilke kararının 3. Maddesinde III.Derece Doğal Sit alanlarının doğal yapısının korunması ve geliştirilmesi kapsamında yörenin potansiyeli ve kullanım özelliği de göz önünde bulundurularak konut kullanımına açılabilecek alanlar olduğu belirtilerek, bu alanlarda kullanıma açılacak bölgelerde, geçici dönem yapılanma koşullarının ilgili kurumların görüşleri alınarak koruma kurullarınca 
belirlenmesine ve bu belirlemede varsa 1/25.000 ölçekli çevre düzeni planı veya 1/5.000 ölçekli nazım imar planı kararları ile arazinin topografya, peyzaj, silüet vb. karakteristiklerinin göz önünde tutulmasına, ancak hazırlanacak Koruma Amaçlı İmar Planı kriterlerini etkileyebilecek nitelik ve yoğunluktaki uygulamalara Koruma Amaçlı İmar Planı yaptırımadan izin verilemeyeceği kararı alınmıştır. Aynı kararda ayrıca Elazığ İli Hazar Gölü ve çevresinin doğal sit alanı olarak korunması amacıyla alan ile ilgili 1/1000 ölçekli uygulama imar planının tescil tarihi ile aynı zamanda Bayındırlık ve İskan Bakanlığı'na yaptırılması ile ilgili karar alınmasına rağmen bugüne kadar böyle bir planın hazırlanmadığı tespit edilmiştir. Bu nedenle yönetmelik gereği 1/25.000 ölçekli çevre düzeni planının temel olarak alınması gerekmektedir. Bu bağlamda bilirkişi heyeti tarafından, halen yürürlükte olan "Malatya-Elazığ-Bingöl-Tunceli 1/100.000 ölçekli Çevre Düzeni Planı" plan kararları incelenmiştir.

Davaya konu konut alanın bulunduğu çevrenin kültürel ve doğal özellikleri kapsamında Çevre Düzeni Planı kararları uyarınca alan; Kullanma Sınırlaması Getirilen Alanlar başlığı altında "Ekolojik Öneme Sahip Alan", "Özel Kanunlara Tabi Alanlar" başlığı altında "Kültür ve Turizm Koruma ve Gelişim Bölgesi/Turizm Merkezi ile Orman ve Ağaçlandırılacak Alanlar başlığı altında "Orman Alanı", Tarımsal Arazi Kullanımları başlığı altında "Tarım Arazisi" statüsünde yer almaktadır (Şekil 3).

Malatya-Elazığ-Bingöl-Tunceli 1/100.000 ölçekli Çevre Düzeni Planı hükümlerinde "Ekolojik Öneme Sahip Alan" tanımında; aynı alanda birden çok doğal niteliğe sahip (su kaynakları, hassas ekosistemler, su ve kara ekosistemleri arasında yer alan geçiş bölgeleri, toprak niteliği ve topografik özellikleri, bitki örtüsü, yaban yaşamı) ya da insan etkisi altında yeniden biçimlenmeden önce bu potansiyele sahip olduğu öngörülen ekolojik ilişki ve etkileşimlerin bütünlük arz ettiği; tür çeşitliliği, iklimsel duyarlılık, su döngüsünün, yaban yaşamının ve insan yaşam ortamlarının kalitesinin sürekliliği açısından korunması öngörülen özel öneme sahip alanları ve doğal koridorları ifade ettiği açıklaması yer almaktadır. Tanımdan yola çıkılarak, çevre düzeni planının 1/100.000 ölçeğinde hazırlanmış olduğu da göz önünde bulundurularak ekolojik öneme sahip alanın ekolojik potansiyelinin bu ölçekte belirlenmesinin sağlıklı olmadığı görülmektedir. Kaldı ki, hali hazırda da bu statü kararının hangi verilere dayanılarak verildiği belirtilmemiştir. Bu nedenle bu alan için daha kapsamlı bir araştırmanın yapılması gerektiği gündeme gelmektedir. Bu kapsamda yapılan araştırmalar sonucunda "Hazar Gölü Havzası'nda Biyolojik Çeşitliliğin Tespiti" ve "Hazar Gölü Sulak Alan Yönetim Planı" başlıklı çalışmalardan yararlanılmıştır. Bu bağlamda Doğa Koruma ve Milli Parklar Genel Müdürlüğü XV. Bölge Müdürlüğü Elazığ Şube Müdürlüğü idaresinde hazırlanan söz konusu çalışmalar araştırma kapsamında incelenmiştir.

Hazar Gölü Havzası Biyolojik Çeşitliliğinin Tespiti çalışmasında Hazar Gölü Sulak Alan Havzası'nda yapılacak fiziki planlama çalışmalarına atlık oluşturacak şekilde; önemli ve geri getirilemez doğal ekosistemlerin tespiti ve korunmasına esas verilerin ortaya konulması, yerel, bölgesel ve ulusal karar vericiler için koruma ve kullanma ilkelerinin belirlenmesi hedeflenmiştir. Çalışmada biyolojik çeşitlilik envanteri ortaya çıkarılmış, bölgedeki tür ve habitatlar EUNIS (Avrupa Doğa Bilgi Sistemi), Ramsar, AB Kuş, AB Habitat Direktifleri ile IUCN Kırmızı Liste kriterlerine göre sınıflandırılmış; tehditler ve koruma önlemleri ortaya konulmuştur (Orman ve Su İşleri Bakanlığı, 2012).

Çalışma kapsamında Hazar Gölü Havzası Biyolojik Çeşitliliğinin Tespiti Sonuç raporunda yer alan flora ve fauna envanter tespit çalışmalarından yararlanılmıştır. Tespit çalışmaları (Karasal Omurgasızlar (Böcekler), Balıklar, Amfibi ve sürüngenler, kuşlar, memeliler başlıkları altında) ve flora çalışmaları gerçekleştirilmiştir. Hazar Gölü Havzası Biyolojik Çeşitliliğinin Tespiti Sonuç Raporu'nda flora ve fauna envanter çalışmalarının metodolojisi olarak Hazar Gölü ve çevresinde gözlem noktaları oluşturulmuştur (Orman ve Su İşleri Bakanlığı, 2012). Alanda belirlenen gözlem noktalarının koordinatlarına göre davaya konu olan parsellerin bulunduğu alana ilişkin biyolojik çeşitlilik tespiti sonuç raporunda, alanda yapılan fauna çalışmalarına göre kuş ve memeli türlerine göre Uluslararası Doğa Koruma Birliği Kırmızı Listesi’ne göre tehlike altında kabul edilen bir türün mevcut olmadığı görülmektedir. Tespit raporu'nda her bir uzmanlık alanı için oluşturulan habitat haritalarına göre koruma zonları belirlenmiştir. Davaya konu olan parsellerin bulunduğu alan ve yakın çevresi belirlenen koruma zonu içinde yer almamaktadır.

Araştırma raporuna göre alanda yapılan floristik araştırmalar çerçevesinde arazi çalışmaları kapsamında belirlenen gözlem noktalarına göre davaya konu olan alan çevresinde endemizm kategorisinde türlerin olduğu saptanmıştır. Belirtilen lokalitide saptanan türler Tablo 1.de yer almaktadır. 
Biyolojik çeşitlilik tespit raporuna göre Tablo 1'de yer alan türlerden Alcea calvertii (Boiss.) Boiss. ve Onobrychis fallax Freyn Et Sınt. türleri endemizm kategorisinde LR (IC) yani en az endişe verici, Wiedemannia orientalis Fisch \& Mey LR (cd) yani koruma önlemi gerektiren tür olarak sınıflandırılmıştır (Orman ve Su İşleri Bakanlığı, 2012). Belirtilen çalışmada yapılan floristik değerlendirmeye göre alan; hassas, tehlikeye düşebilir veya tehlike altındaki türler veya tehdit altındaki ekolojik türlerle desteklenmediği kararı araştırma raporunda yer almaktadır. Endemik türlerin yayılış alanları bölgesel olarak belirlendiğinden belirtilen türlerin davaya konu olan alan sınırları içinde varlığına ilişkin detaylı noktasal ölçümlerinin yapılması gerekmektedir.

MALATYA-ELAZIĞ-BiNGÖL-TUNCELI PLANLAMA BÖLGESI 1/100.000 ÖLÇEKLI ÇEVRE DÜZENI PLANI

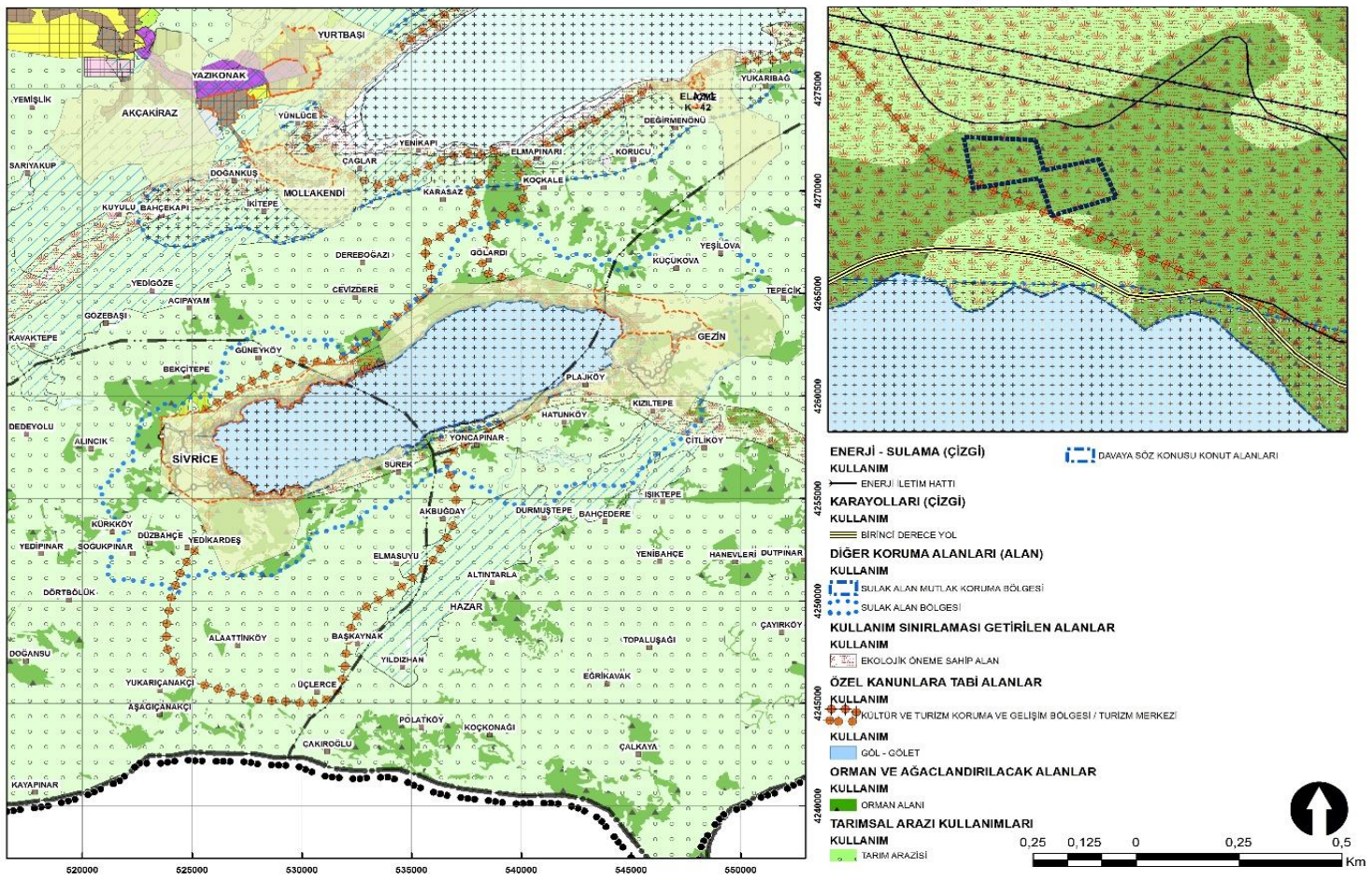

Şekil 3. Malatya-Elazığ-Bingöl-Tunceli 1/100.000 ölçekli Çevre Düzeni Planı içinde Hazar Gölü ve Hazar Gölü çevresinde davaya söz konusu olan konutlar (Çevre Düzeni Planı kullanılarak oluşturulmuştur) (Çevre ve Şehircilik Bakanlığı, 2015)

Tablo 1. Arazi gözlem noktalarına göre davaya konu olan parsellerin bulunduğu alan çevresinde tespit edilen endemik türler (Orman ve Su İşleri Bakanlığı, 2012).

\begin{tabular}{|c|c|c|c|c|c|}
\hline TÜR & $\begin{array}{l}\text { Takım, Familya, } \\
\text { Cins ve Tür adı }\end{array}$ & Habitat & Element & Endemizm & $\begin{array}{l}\text { Populasyon } \\
\text { Yoğunluğu }\end{array}$ \\
\hline \multicolumn{6}{|c|}{ MALVACEAE } \\
\hline 1. & $\begin{array}{l}\text { Alcea calvertii (Boiss.) } \\
\text { Boiss. }\end{array}$ & $\begin{array}{l}\text { Aşınmış kıyılar, } \\
\text { yamaçlar, } \\
\text { volkanik tepeler }\end{array}$ & $\begin{array}{l}\text { İran- } \\
\text { Turan }\end{array}$ & $\begin{array}{l}\text { Endemik LR } \\
\text { (Ic) }\end{array}$ & Az yoğun \\
\hline \multicolumn{6}{|c|}{ FABACEAE } \\
\hline 2. & $\begin{array}{ll}\text { Onobrychis } & \text { fallax } \\
\text { Freyn Et Sint. } & \end{array}$ & $\begin{array}{l}\text { Kireçtaşı, } \\
\text { yamaçlar bozkır }\end{array}$ & $\begin{array}{l}\text { İran- } \\
\text { Turan }\end{array}$ & $\begin{array}{l}\text { Endemik LR } \\
\text { (Ic) }\end{array}$ & Yoğun \\
\hline \multicolumn{6}{|c|}{ LAMIACEA } \\
\hline 3. & $\begin{array}{l}\text { Wiedemannia } \\
\text { orientalis Fisch \& Mey }\end{array}$ & $\begin{array}{l}\text { Taşlı tepelikler, } \\
\text { bozkır, tarlalar, } \\
\text { bağlar, yol } \\
\text { kenarları }\end{array}$ & $\begin{array}{l}\text { İran- } \\
\text { Turan }\end{array}$ & $\begin{array}{l}\text { Endemik LR } \\
\text { (cd) }\end{array}$ & \\
\hline
\end{tabular}

Farklı ekolojik karakterdeki sulak alanlara sahip olan Hazar Gölü ve çevresinin ekolojik dengesinin korunması amacı ile Çevre ve Orman Bakanlığı Doğa Koruma ve Milli Parklar Genel Müdürlüğü Doğa Koruma Dairesi Başkanlığı Sulak Alanlar Şube Müdürlüğü koordinesinde 
hazırlanan Hazar Gölü Sulak Alan Yönetim Planı ilgili birimden talep edilmiştir. Sulak Alan Yönetim Planı'nda yapılan araştırmalar sonucunda "Ekolojik Etkilenme Koruma Bölgeleri" haritası dikkate alınmıştır. Oluşturulan haritaya göre davaya konu olan alanın "Tampon Bölge Sınırı" içinde yer aldığı görülmektedir (Şekil 4).

Hazar Gölü Yönetim Planı'nda tampon bölge sınırları içinde Göl'ün ekolojik özelliklerini etkileyecek şekilde faaliyetlerde bulunulamayacağı ve bu bölgede tarım, hayvancılık ve kontrollü turizm faaliyetleri ve Sulak Alanların Korunması Yönetmeliği hükümleri dışında bir faaliyete izin verilemeyeceği Sulak Alanların Korunması Yönetmeliği kapsamında, tampon bölge içerisinde halen faaliyet gösteren işletmeler ile yeni talepler için Genel Müdürlük'ten izin alınması gerektiği kararları alınmıştır. Yönetim planı kararlarına göre söz konusu alan, tampon bölge sınırları içinde yer almaktadır. Yönetim planı kararları gereği bu alanlar tarım, hayvancılık, kontrollü turizm faaliyetleri dışında başka faaliyetlere izin verilemeyecek alanlar olduğundan davaya konu olan parsellerin olduğu alanın bu maddeyi ihlal ettiği görülmektedir. Ancak yönetim planı 30.01.2002 yılında yayımlanmış ve 17.05.2005 tarihinde revize edilerek yürürlüğe girmiştir (Çevre ve Orman Bakanlığı, 2011). Bahsi geçen konutların bu tarihlerden önce inşa edildiği bilindiğinden bu konuda plan kararlarına aykırılıktan bahsedilemeyeceği düşünülmektedir. Ayrıca davaya konu olan alan, yönetim planı kararında "Hazar Gölü Sulak Alan Koruma Bölgeleri Özel Hüküm Bölgeleri" sınırları içinde de yer almamaktadır.

\section{SONUC}

Kültür ve Tabiat Varlıklarını Koruma Kanunu aracılığıyla ilan edilen doğal sitler genel olarak değerlendirildiğinde, özellikle görsel doğal güzellikleri, biyolojik çeşitlilik, ekolojik hizmet ve katkıları (özellikle karbon tutma ve depolama görevi), ekolojik besin, temiz su, yerel kültür ve ürün potansiyeli, turizm/rekreasyon açısından cazip konumda olması gibi söz konusu değerlerin ve varlıkların geleceğe yönelik korunması ve geliştirilmesi bağlamında toplum yararına hizmet verebilecek önemli role sahiptir. Doğal sit derecelendirilmesindeki amaç, koruma alanlarının belirlenmesi, sınıflandırılması ve korunması gereken alanların koruma amaçlarını belirleyerek mevcut duruma uygun yönetim ve koruma stratejilerinin ortaya konulmasını sağlamaktır. Doğal sit olarak saptanan yerlerin kendi içinde ve çevresi ile olan ekolojik ilişkileri ve bu iliş̧kilerin denge unsuru olan doğal kaynaklar göz ardı edildiğinden kamuoyu doğal sitleri sürekli olarak görselliğin ön planda olduğu güzellik, olağanüstülük gibi niteliklerle değerlendirmektedir. Oysa ki, doğal sitler; topografik, hidrolojik, biyolojik, estetik, algısal, kültürel, tarihsel değeri olan ender kaynaklardır (Gülez, 1984).

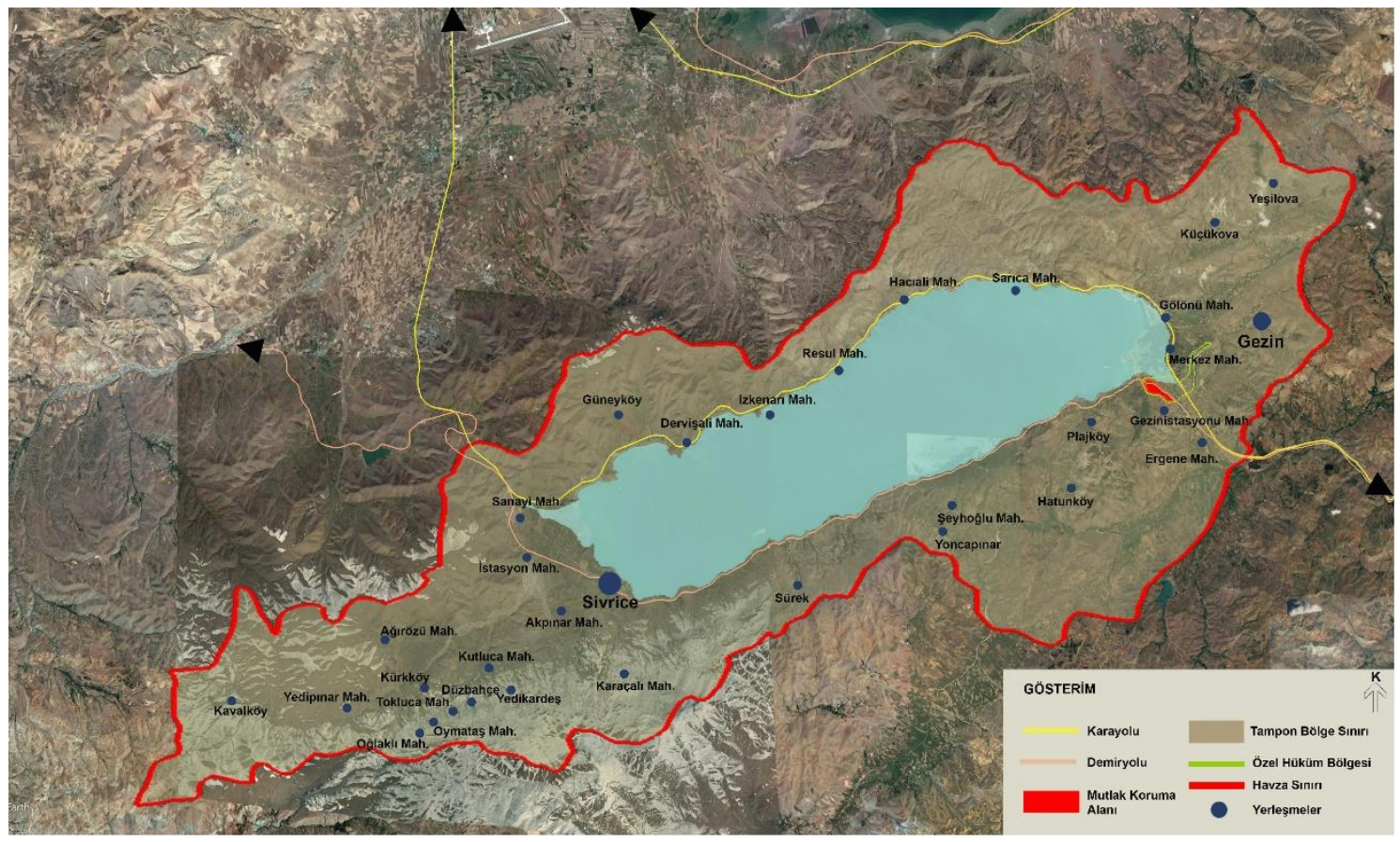

Şekil 4. Sulak Alan Yönetim Planına göre "Koruma Bölgeleri" ve davaya konu alanın konumu (Çevre ve Orman Bakanlığı Doğa Koruma ve Milli Parklar Genel Müdürlüğü tarafından hazırlanan Hazar Gölü Yönetim Planından yararlanılarak hazırlanmıştır)(Çevre ve Orman Bakanlığı, 2011). 
Yapılan arazi incelemeleri ve ilgili kurumlardan alınan çalışmalar doğrultusunda davaya konu olan alan ile ilgili olarak hazırlanan bilirkişi raporunda aşağıdaki maddeler yer almıştır.

- Koruma Kurulu'nun aldığı tescil kararının derecelendirmeye temel alınacak, sınırların hangi ölçüte göre değerlendirildiği, hangi koordinatlara göre geçirildiği ve hangi verilere dayanarak sınır çizgilerinin belirlendiği ile ilgili bilimsel verilere rastlanılmamıştır. Harita üzerinden belirli bir ölçüte dayandırılmadan geçirilen sınır çizgileri, mülkiyet ve yapılaşma haklarının kullanımını kısıtlamakta ve mağduriyetler yaşanmasına sebebiyet vermektedir.

- Sorunların çözülmesi ve korunan alanlarda yapılaşma koşullarının belirlenmesi için kanunda da belirtildiği üzere "Koruma Amaçlı İmar Planı́nın hazırlanması gerekmektedir. Hazar Gölü ve çevresi doğal sit tescil kararının verildiği 1991 yılından bugüne kadar bu planın hazırlanmaması bir eksikliktir. Bu durum gelecekte sorunların daha da artmasına neden olacaktır.

- Koruma Amaçlı İmar Planı́nın dayanağını oluşturacak çalışma kapsamında bahsi geçen "Ekolojik Temelli Bilimsel Araştırma Raporu'nun konunun uzmanlarınca ivedilikle hazırlanması son derece önemlidir.

- Araştırma sürecinde elde edilen veriler kapsamında bu rapora temel oluşturacak çalışmaların mevcut olduğu görülmektedir. Tespit raporuna göre yapılan fauna ve flora araştırmaları Çevre ve Şehircilik Bakanlığı Tabiat Varlıklarını Koruma Genel Müdürlüğü’nün hazırlamış olduğu "Doğal Sit Alanlarının Değerlendirilmesine İlişkin Teknik Esaslar" adlı uygulama rehberinde yer alan başlıklardır.

- Uygulama rehberine göre doğal sit alanı belirlenirken ve kategorize edilirken belirlenen biyolojik kriterlerin nitel ve nicel olarak analiz edilmesi, çeşitli istatistiki yöntemlerin kullanılarak (Analitik Hiyerarşik Süreci vb. gibi) değerlendirme yapılması ve bir dizi kapsamlı çalışmayı gerekli kılmaktadır. Bu nedenle mevcut çalışmalar Hazar Gölü ve çevresi doğal sit sınırlarının belirlenmesi ve sit alanlarının kategorize edilmesinde tek başına yeterli değildir.

- Hazar Gölü ve Havzası'ndaki yapılaşmalar ve gittikçe artan insan baskısı, tür alanlarını ve popülasyon yoğunluklarını olumsuz yönde etkilediği, rastgele ve hızlı yapılaşmanın bölgenin doğal özelliklerini bozduğu gözlemlenmiştir. Bu anlamda Hazar Gölü'nün (davacının dosyada yer alan ifadesine atfen) yalnızca görsel özelliklerinden dolayı değil, doğal karakteri nedeni ile bir bütün olarak (doğal tektonik yapısı, sahip olduğu biyoçeşitliliği vb.) kamu yararı açısından mutlaka korunması amacı ile yapılaşma faaliyetlerinin kontrollü olması gerekmektedir. Bu kapsamda, Koruma Amaçlı İmar Planı'nın ivedilikle hazırlanarak yapılaşma ile ilgili belirsizliklerin ortadan kaldırılmalıdır.

Arazi gözlem- tespit çalışmaları, dava konusu alana ilişkin ilgili kararlar ile yapılan çalışmaların incelenmesi sonucu yukarıda belirtilen eksiklikleri ve önerileri içeren bilirkişi raporu sayın mahkemenin takdirine sunulmuştur.

Doğal sit derecelendirme sorunu bugün, çalışma kapsamında incelenen dava konuları ile araştırma kapsamında incelenen örnekte olduğu gibi ülke genelinde yaşanılan önemli bir sorundur. Kırsal alanlardan kentlere yoğunlaşan göç, paralelinde yaşanan hızlı kentleşme, ikinci konut ve turizm amaçlı kıyı yapılaşması, arazi rant eğilimleri, mevzuatın uygulanamayışı, imar afları yanında sitlere yönelik karar verme zaman sürecinin uzun tutulması, kamuoyunda bu alanlara ait beklenti ve baskıları gündemde tutmakta, bunun da ötesinde sit kararları etkinliğini yitirebilmektedir. Karar verme süreçlerinde başlıca sorunlardan biri, doğal sitlerin işleyişini ortaya koyan ekolojik araştırma ve metodolojik yaklaşımlardaki eksikliklerdir (Türkyılmaz, 2005). Gül vd.' nin (2007) ifadesi ile gerçek anlamda doğa koruma arzulanıyor ise; ülke ölçeğinden yerel ölçeğe kadar doğal kaynaklara yönelik koruma ve ekonomi politikaları, bu kaynakların sektörel ölçekteki paylaşımı, üretim-tüketim ilişkileri gibi çok yönlü yönetim politikalarını ya da önceliklerinin kamuoyu önünde net bir şekilde ortaya konulması gerekmektedir. Diğer taraftan; yürürlükte yer alan yeni yönetmelikle birlikte herhangi bir koruma alanının güncel durumu ortaya konulmadan koruma statüsünün değerlendirilemeyeceği, güncel durum tespitinde ise, alanın biyolojik çeşitliliği, hidrolojisi, hidrojeolojisi başta olmak üzere tüm kriterler açısından ekolojik temelli bilimsel araştırmanın yapılması yükümlülüğünün getirilmiş olması yaşanan mağduriyetlerin çözümünde etkin olacağı düşünülmektedir.

\section{KAYNAKLAR}


Akgedik, H. (2013). Danıştay Kararları Işı̆̆ında Hidroelektrik Santraller, Türkiye Adalet Akademi Dergisi, 4/15

Çevre ve Orman Bakanlığı, (2011). Hazar Gölü Sulak Alan Yönetim Planı, Doğa Koruma ve Milli Parklar Genel Müdürlüğü, Elazığ

Çevre ve Şehircilik Bakanlığı http://www.csb.gov.tr/gm/tabiat/index.php?Sayfa=sayfa\&Tur=webmenu\&ld=8969, Erişim Tarihi: 10.03 .2017

Çevre ve Şehircilik Bakanlığı (2013b). Doğal Sit Alanlarının Değerlendirilmesine İlişkin Teknik Esaslar, http://www.csb.gov.tr/db/tabiat/editordosya/Teknik_esaslar_04032013.pdf, Erişim Tarihi: 09.01.2017

Çevre ve Şehircilik Bakanlığı (2015). Malatya-Elazığ-Bingöl-Tunceli Çevre Düzeni Plan Kararları, http://mpgm.csb.gov.tr/malatya---elazig---bingol---tunceli-planlama-bolgesi-i82187, Erişim Tarihi: 09.01.2016

Diyarbakır Kültür ve Tabiat Varlıklarını Koruma Kurulu Arşivi

Dudley, N. (2008). Guidelines for Applying Protected Area Management Categories (Editor: N. Dudley) Gland, Switzerland, ISBN: 978-8317-1086-0.

Duran, C., Günek, H. (2007). Hazar Gölü Havzası Arazi Kullanımındaki Değişikliklerin Belirlenmesi (1956-2004), Fırat Üniversitesi Sosyal Bilimler Dergisi, 17(2):31-52, Elazığ

Eröksüz, C. (2016). Korunan Alanlar Doğal Sit ve İlgili Mevzuat, Adalet Yayınevi, ISBN: 978605-146-808-2, Ankara.

Gökçeoğlu, C. ve Ayaş, Z. (2012). Doğal Sit Alanlarının Belirlenmesi ve Derecelendirilmesinde Biyo-ekolojik ve Jeolojik Yaklaşımlar, T.C. Çevre ve Şehircilik Bakanlığı Tabiat Varlıklarını Koruma Genel Müdürlüğü Tabiat Varlıklarının Korunması: Biyolojik Çeşitlilik ve Korunan Alanlar Eğitim Semineri, Antalya

Gül, A., Özgüner, H., Özsu, O. (2007). Ülkemizdeki Doğal Sit Alanlarının Planlanması ve Yönetiminde Peyzaj Mimarlığının Rolü, 3.Binyılda Peyzaj Mimarlığı Kongresi, HedeflerStratejiler-Politikalar, Antalya

Gülez, S. (1984). Doğal Anıtların Sınıflandırılması, Tabiat ve İnsan Dergisi, Yıl: 18, Sayı:1, Ankara.

IUCN, 2008. The International Union for Conservation of Nature, https://www.iucn.org/about Erişim Tarihi: 10.03.2018.

IUCN, 2016. Protected Planet Report 2016, https://www.protectedplanet.net/c/protectedplanet-report-2016, Erişim Tarihi: 02.03.2018

Koç, B. (2006). Tanzimat Sonrası Hukuk Metinlerinde Çevre Bilincinin Arka Planı Olarak "Av Yasak ve Sınırlılıkları" Üzerine Bazı Düşünceler, Ankara Üniversitesi Osmanlı Tarihi Araştırma ve Uygulama Merkezi Dergisi, Sayı:19.

Kurdoğlu, Oğuz. (2007). Dünyada Doğayı Koruma Hareketinin Tarihsel Gelişimi ve Güncel Boyutu, Artvin Çoruh Üniversitesi Orman Fakültesi Dergisi, 8 (1), 59-76

Kültür ve Turizm Bakanlığı, (1999). Kültür ve Tabiat Varlıklarını Koruma Yüksek Kurulu İlke Kararları http://www.kulturvarliklari.gov.tr/TR,44334/ilke-karari--karar-no-728--karartarihi-19062007.html Erişim Tarihi: 02.01.2017

Orman ve Su İşleri Bakanlığı, (2012). Hazar Gölü Havzası Biyolojik Çeşitliliğin Tespiti Projesi, XV.Bölge Müdürlüğü- Elazığ Şube Müdürlüğü, Elazığ

Resmi Gazete, (2012). Korunan Alanların Tespit, Tescil ve Onayına İlişkin Usul ve Esaslara Dair Yönetmelik, http://www.resmigazete.gov.tr/eskiler/2012/07/20120719-3.htm Erişim Tarihi: 19.01 .2018

TMMOB Orman Mühendisleri Odası, (2018) Mevzuatlar, Korunan Alanlar (III.Aşama:Planlama), http://ormuh.org.tr/arsiv/files/Planlama.pdf, Erişim Tarihi: 19.01.2018

Türkyılmaz, B. (2012). Doğal Sitler-İzmir ve Çevresinde İrdelenmesi, TMMOB Kent Sempozyumu, Ankara 
URL-1, (2018). http://www.parcoabruzzo.it/page.php?id=251 Erişim Tarihi: 17.03.2018

URL-2, (2018). https://www.canada.ca/en/environment-climatechange/services/environmental-indicators/protected-areas.html ,Erişim Tarihi: 17.03.2018.

Vuruşkan A., Ortaçesme V. (2009). Antalya Kentindeki Doğal Sit Alanlarına İlişkin Sorunların İrdelenmesi, Akdeniz Üniversitesi Ziraat Fakültesi Dergisi, 2009, 22(2), 179-190

\section{EXTENDED ABSTRACT}

The term "natural protected area", as peculiar to Turkey, is of crucial importance in terms of protection of natural landscape sources within the scope of built environment relation. However, taking subjective and alternating decisions instead of scientific decision, which are required to be taken in accordance with the ecological planning and conservation criteria in the protection of natural landscapes during the dense housing process lead victimization of local residents, pitting them against the public institutions and organizations. On the other hand, a threat for the ecological characteristics of natural protected areas to retrogress arises due to the decision taken in line with the housing process. This problem, which is faced in the natural protected areas, is analyzed in this study within the scope of the case study, which was brought to the provincial administrative court for the immovables located around the Hazar Lake in Elazığ province, as subjected to various natural protected area rating.

The main material of the research comprises of the report, prepared by the commission of experts within the scope of decision no.: 856, dated as 11.07.1991, taken by Diyarbakır Cultural and Natural Heritage Conservation Board, where the demolition procedures were decided to be initiated claiming that the houses around Hazar Lake in Elazığ were located within the natural protected areas, to which the house owners appealed for reversal, while the court decided a report to be drawn up on whether the area of immovable bears the characteristics of a natural protected area considering the environmental, landscape, topographical, skyline, etc. aspects, and whether the immovable is suitable based on its characteristics,

The methodology of the research is of a three-stage process, as follows: analysis of the case file, including the data obtained and requested from the respective bodies, by the author personally in the capacity of an expert; comparison of the data obtained following the field survey works and land works carried out with environmental engineer, survey engineer, geology engineer and urban planner, with the report presented to the court by the respective bodies; and evaluation of State Council Decisions on precedent cases.

Within the scope of the research, the decisions taken by Diyarbakır Cultural and Natural Heritage Conservation Board, Malatya-Elazığ-Bingöl-Tunceli 1/100.000 Scaled Environmental plan decisions, as well as the Detection of Biological Diversity in Hazar Lake and Hazar Lake Wetland Management Plan were analyzed and reviewed within the context of field survey works. The decision-making process on whether the area of immovables in dispute bear the characteristics of natural protected area, or not, was stated in accordance with the obtained data.

Following the research, it was stated in the expert report on the area in dispute in line with the studies \& works carried out by the respective authorities, including the field surveys that:

- The "natural protected area" registry decision, taken by the Conservation Board, was not regulated as per the scientific criteria to be based for rating.

- The housing and ever-increasing community pressure around Hazar Lake and Basin had a negative impact on the nature and population density; and random \& rapid housing adversely affect the natural characteristics of the area.

In this sense, it was outlined that the housing activities must be carried out under control for Hazar Lake to be protected in its entirety (natural tectonic structure, biological diversity it has, etc.) in terms of public welfare not only due to its visual characteristics, but also its natural characteristics. 
It was concluded that Conservation Oriented Development Plan must be drawn up as the solution of current building pressure problem, and that "Ecologic Basis Scientific Research Report" must be drawn up by the respective experts without delay of time, as introduced and prescribed by the Ministry of Environment and Urbanization, which will constitute the basis of Conservation Oriented Development Plan. 